\title{
Occurrence of large granular lymphocytes and natural killer cells in the epithelium of the gut distinguishes two different coeliac diseases
}

\author{
F Hadziselimovic, L R Emmons, Ursula Schaub, E Signer, Annemarie Bürgin-Wolff, R Krstic
}

\begin{abstract}
In a longterm study, we have divided coeliac disease into two distinct entities (abortive and permanent) based on the occurrence of large granular lymphocytes and natural killer cells within the epithelium of the gut. The natural killer and large granular lymphocytes cells were characterised by either immunohistochemical or phase contrast microscopical procedures on the initial biopsies from 15 children with coeliac disease. They were compared with seven individuals with partial villus atrophy and eight with normal villous morphology. Although the histological findings were similar in the initial biopsies of all patients with coeliac disease, the patients with permanent coeliac disease had a significantly lower number $\left(0.41(0.61)\right.$ cells $\left./ \mathrm{mm}^{2}\right)$ of large granular lymphocytes and natural killer cells compared with those patients with abortive coeliac disease $\left(11.93(6.23)\right.$ cells $\left./ \mathrm{mm}^{2}\right)$. Those in the permanent group developed a significantly more pronounced flat mucosa after gluten challenge or provocation compared with the abortive group and had to remain on a strict gluten free diet in contrast with those in the abortive group. Thus, the occurrence of intraepithelial large granular lymphocytes and natural killer cells characterises two distinctly different coeliac diseases. Based on our results neither the histological evaluation of the biopsy nor the utilisation of the revised European Society for Paediatric Gastroenterology and Nutrition (ESPGAN) Criteria are adequate in diagnosing the two types of coeliac disease.
\end{abstract}

Coeliac disease is a gluten sensitive enteropathy resulting in a flat intestinal mucosa, high plasma antigluten $\operatorname{IgG}, \operatorname{IgA}$, and antiendomysium (reticulin) antibodies in addition to the well known clinical appearance with pronounced malnutrition. ${ }^{1-3}$ The disease varies in severity from patient to patient. Even within a single family, patients with latent totally asymptomatic disease, and patients with severe symptoms, unless treated, may develop into a disabling disease. It has long been thought that patients with coeliac disease should remain on a life long gluten free diet; particularly as Holmes $e t$ al have suggested that the diet protects from developing malignancies of the gastrointestinal tract. ${ }^{+}$

Moreover, Kelly et al have recently reported that 26 of 218 children who were initially diagnosed with coeliac disease did not suffer a relapse after the reintroduction of gluten into their diet. Thus these 26 patients would be diagnosed with what has been referred to in the literature as

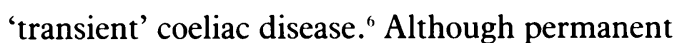
intolerance to gluten in coeliac patients is current pediatric opinion, Schmitz et al have reported the spontaneous recovery of coeliac disease in children who were maintained on a normal diet with gluten challenges. ${ }^{7}$ This is particularly significant because the aetiology of coeliac disease is still an enigma.

In this study, we have analysed the clinical and the histological features of 15 coeliac patients in a longterm follow up of their disease, and have correlated the occurrence of large granular lymphocytes and natural killer cells within the epithelium of the gut with respect to disease activity.

\section{Methods}

PATIENTS

Fifteen patients diagnosed with coeliac disease, according to the revised European Society of Pediatric Gastroenterology and Nutrition (ESPGAN) Criteria, ' were included in the study. The flat intestinal mucosa was identified independently by three investigators with three different methods: stereomicroscopy, histologically stained tissue sections, and scanning electron microscopy.

All the patients have been followed from the time of their first intestinal biopsy for an average period of $15( \pm 3 \cdot 6)$ years.

A standard biospy procedure was carried out at the duodenojejunal junction with a Watson capsule under fluoroscopic control. The biopsy was analysed with a stereomicroscope and was sent to an experienced pathologist for histological examination. All initial biopsies, as well as the biopsies of seven patients in remission, were fixed additionally in $2 \%$ glutaraldehyde for electron microscopy as well as immunohistochemical evaluations. The duration of gluten challenge was defined as the period of time between the onset of the gluten challenge and when the third intestinal biopsy was performed in each patient. Seven prepubertal patients with recurrent abdominal pain were examined endoscopically because of suspected gastric or duodenal ulcers. Subsequent histological examination of the biopsies, however, revealed no inflammation and were assumed to be normal. These seven served as a control group for the distribution of large granular lymphocytes and natural killer cells within the epithelium. Patients with cow's milk allergy (four), giardiasis (two), and congenital lactose intolerance (one), all with partial villus atrophy, were taken as disease controls.

All patients were examined regularly in the 
TABLE I Number of large granular lymphocytes and natural killer cells $/ \mathrm{mm}^{2}$ in the epithelium of the gut

\begin{tabular}{|c|c|c|c|c|c|}
\hline \multirow[b]{2}{*}{ Patient } & \multicolumn{2}{|c|}{ Active coeliac disease } & \multirow{2}{*}{$\begin{array}{l}\text { Coeliac disease in } \\
\text { remission }\end{array}$} & \multirow{2}{*}{$\begin{array}{l}\text { Partial villus } \\
\text { atrophy }\end{array}$} & \multirow{2}{*}{$\begin{array}{l}\text { Normal villus } \\
\text { morphology }\end{array}$} \\
\hline & Permanent form & Abortive form & & & \\
\hline 1 & 0 & $4 \cdot 1$ & $10 \cdot 5$ & $13 \cdot 6$ & $22 \cdot 2$ \\
\hline 2 & 0 & $20 \cdot 0$ & $8 \cdot 2$ & $15 \cdot 8$ & $9 \cdot 6$ \\
\hline 3 & 0.57 & 19 & $8 \cdot 45$ & $3 \cdot 5$ & $25 \cdot 7$ \\
\hline 4 & 1.6 & 6.8 & $22 \cdot 7^{\star}$ & $7 \cdot 9$ & $3 \cdot 5$ \\
\hline 5 & 0 & $14 \cdot 9$ & $10 \cdot 0^{\star}$ & $10 \cdot 2$ & $10 \cdot 2$ \\
\hline 6 & 0 & $18 \cdot 0$ & $3 \cdot 3^{\star}$ & $18 \cdot 3$ & 3.9 \\
\hline 7 & 0 & $5 \cdot 4$ & $3 \cdot 8$ & $13 \cdot 75$ & $13 \cdot 8$ \\
\hline & & $\begin{array}{l}7 \cdot 2 \\
x=11.93(6.23)\end{array}$ & & & \\
\hline mean $(\mathrm{SD})$ & $x=0.31(0.61)$ & $x=11.93(6.23)$ & $\times=9 \cdot 56(6.44)$ & $x=11.86(4.65)$ & $x=12 \cdot 7(8 \cdot 5)$ \\
\hline
\end{tabular}

^Abortive disease in remission. polyvalent goat antimouse IgG (whole molecule) gold conjugate, $10 \mathrm{~nm}$ (Sigma Chemical Co, St Louis, MO, USA product no G 0646) was diluted $(1: 50)$ in $\mathrm{PBS}^{++}$and incubated and processed in the same manner described for the primary antibody.

The gold particles were visualised with a light microscope by means of a silver enhancement procedure (Sigma Chemical Co, St Louis, MO, USA. cat\# SE-100) The large granular lymphocytes were visualised with a Zeiss Photomicroscope III equipped with phase contrast features.

Photographs were taken with a Zeiss Photomicroscope III using Kodak $\mathrm{T}_{\text {MAX }} 400$ film with phase contrast objectives plus a blue conversion filter.

Department of Gastroenterology from the time of their initial diagnosis to the present time. Patients had detailed case histories prepared, clinical examinations, biochemical blood analyses, and antigluten antibody titres were determined at six to 12 month intervals. A fluorescent immunosorbent test was used for determining the antibody titre; the details of the assay are described elsewhere. ${ }^{3}$

\section{HISTOCHEMICAL AND IMMUNOCHEMICAL} PROCEDURES

Immunohistochemical procedures to determine the distribution of natural killer cells were carried out on semithin sections from the initial biopsy of all patients and in seven of the 15 who were in remission (Table I). At least three different regions of the biopsy were examined, and a minimum area of $1 \mathrm{~mm}^{2}$ of mucosa was analysed statistically. The area of the sections was determined with the aid of a camera lucida. The biopsies were fixed in $2 \%$ glutaraldehyde in phosphate buffered saline $(0 \cdot 15 \mathrm{M} \mathrm{NaCl}, 0.01 \mathrm{M}$ phosphate buffer, $\mathrm{pH} 7 \cdot 3$ ) (PBS) for one to two hours at room temperature and then left overnight at $4^{\circ} \mathrm{C}$. Tissue samples were then rinsed several times in phosphate buffered saline (PBS) (10 minutes each time) and immersed in 0.05 M $\mathrm{NH}_{4} \mathrm{Cl}$ in phosphate buffered saline for 30 minutes to neutralise the free aldehyde groups. After rinsing three times ( 10 minutes each) in phosphate buffered saline, the tissue was dehydrated in graded ethanols and embedded in Epon 812.

Semithin sections $(0 \cdot 5-1 \cdot 5 \mu \mathrm{m})$ were mounted on polylysine treated $(1 \mathrm{mg} / \mathrm{ml}$ for five minutes) glass slides. The epon was removed (not etched) according to Maxwell, ${ }^{8}$ after which the slides were immersed in Lugol's solution ( $1 \%$ iodine in $2 \%$ aqueous potassium iodide) for five minutes; then washed thoroughly before rinsing in $2.5 \%$ aqueous sodium thiosulfate solution for three minutes. The slides were rinsed in gently running tap water for five minutes then transferred to distilled water.

Natural killer cells were identified immunohistochemically by means of a specific monoclonal antibody, anti-Leu 11 (Becton-Dickinson). The antibody was diluted (1:20) in $\mathrm{PBS}^{+++}$ ( $1 \%$ goat serum, $0.05 \%$ Tween 20 , and $0.1 \%$ Triton-X). The primary antibody incubation was for one and one half hours at $25^{\circ} \mathrm{C}$. The slides were washed in phosphate buffered saline three times (10 minutes each). A second antibody,
SCANNING ELECTRON MICROSCOPY (SEM)

Tissue blocks were postfixed in $1 \% \mathrm{OsO}_{4}$, dehydrated and dried to a critical point, and then fixed on Scanning electron microscopy specimen holders, coated with gold and observed with JEOL JSM-35 scanning-electron microscope at $25 \mathrm{kV}$.

HISTOMETRY IN VILLI patients included in the longterm follow up were measured with the aid of an ocular micrometer. Ten consecutive villi were measured in each section and their lengths were averaged.

\section{STATISTICAL ANALYSES}

Analyses were performed with the WilcoxonMann-Whitney-U-test and the Fischer exact test.

\section{Results}

All of the coeliac patients in our study group had the following four characteristics in common: (a) a flat intestinal mucosa as judged by three different independent observers using different techniques. No significant differences were observed among the three different investigators on the state of mucosal pathology. Furthermore, the mucosa was found to be normal in 14 of 15 patients before being rechallenged with gluten although one patient initially had a slightly partial atrophy of the villi; (b) a high initial antigluten antibody titre that declined and reached normal values within six months while on a gluten free diet; (c) they showed an unequivocal response towards normalisation of their symptoms during the gluten free diet; (d) the plasma iron concentration was lower than normal; (e) all patients fulfilled old and revised ESPGAN Criteria. ${ }^{19}$

Although all the coeliac patients in our study group were characterised with the above criteria, two distinct groups of coeliac patients were categorised by the distribution of large granular lymphocytes and natural killer cells within the epithelium in the initial biopsy of the duodenojejunal mucosa. One group (abortive type) had the normal number of large granular lymphocytes
All of the histological sections of the biopsies of and natural killer cells $\left(11.93(6.23)\right.$ cells $\left./ \mathrm{mm}^{2}\right)$ 


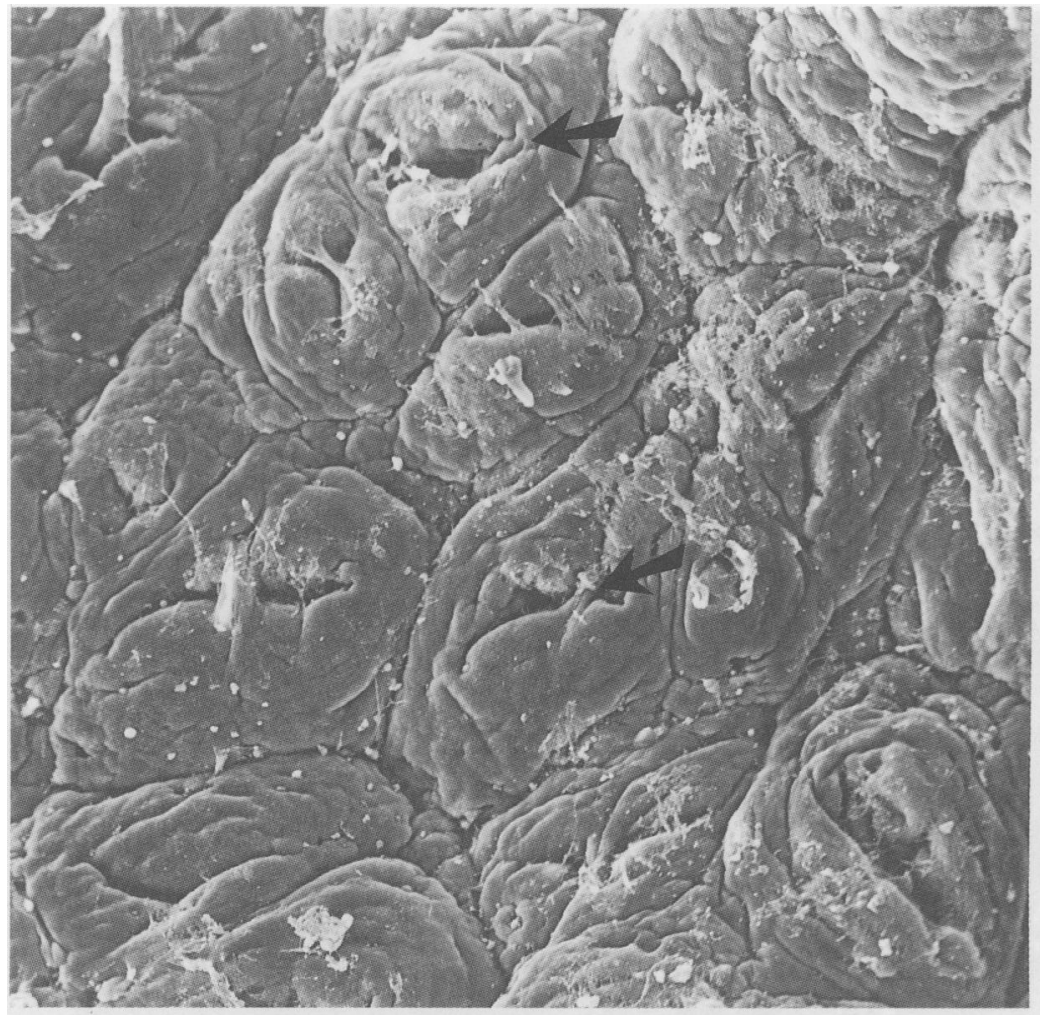

(a)

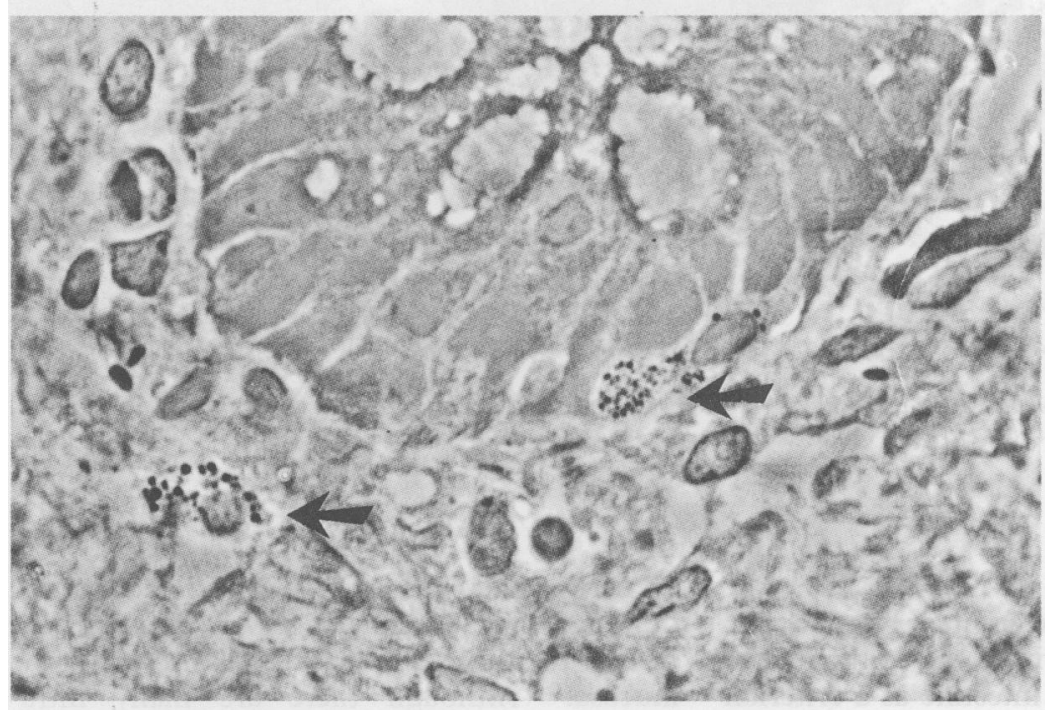

(b)

Figure 1: (a) Scanning electron photomicrograph of the flat mucosa in a patient with abortive coeliac disease which illustrates only crypts (arrows). (b) Phase contrast photomicrograph of the semithin section from the same patient illustrating the natural killer cells and large granular lymphocytes (arrow). was significantly distinctive (Table II, III). Thus the patients in the abortive group who had intraepithelial large granular lymphocytes and natural killer cells reacted clinically less dramatically (no diarrhoea, abdominal pain, nor anaemia) after gluten challenge while those in the permanent group continued to have severe symptoms when gluten challenged.

Patients on a gluten free diet and in full remission with a normal intestinal morphology had a large granular lymphocytes and natural killer cell distribution $\left(9 \cdot 56(6.44)\right.$ cells $\left./ \mathrm{mm}^{2}\right)$ that was comparable with that found in the controls $\left(12.64(8.79)\right.$ cells $\left./ \mathrm{mm}^{2}\right)$ and patients with partial villus atrophy $(15 \cdot 23(5 \cdot 97)$ cells/ $\mathrm{mm}^{2}$ ) caused by either cow's milk allergy, giardiasis, or congenital lactose intolerance (Table I). This was irrespective of the group to which the patient was initially assigned. Thus, the duodenojejunal epithelium of the permanent coeliac disease group that initially lacked large granular lymphocytes and natural killer cells became repopulated with natural killer cells during a gluten free diet. Seven of the eight patients of the abortive group in our longterm study were clinically asymptomatic. They were living normal lives and were not on a strict gluten free diet. Their most recent antigluten antibody titres were negative for IgA and IgG except for one of the eight who had a low antigluten IgG titre.

This was in sharp contrast with the permanent coeliac group where $100 \%$ of patients had to adhere to a strict gluten free diet. Four of the seven patients in this group, however, were still on a strict gluten free diet and were living relatively normal lives. The other three admitted that they had ingested gluten once or several times a week. Two are now 20 and 26 years of age and their current body weight is below the third percentile. The weight to height indices was $81 \%$ and $91 \%$ respectively. The third patient $(25$ years) had a normal weight to height index $(100 \%)$. All three suffered from pronounced iron deficient anaemia and from severe diarrhoea periodically. Neither the age when coeliac disease was diagnosed nor the duration of the gluten free diet before the rechallenge differed significantly between the two groups (Table II). Furthermore, there was no significant difference in the age of both groups when the rechallenge with gluten was initiated (Table II). During the rechallenge all patients developed mucosal relapse. Although the rechallenge time was the same in both groups, patients with permanent coeliac disease developed flat mucosa significantly more often than those in the abortive group (Tables III, IV). In addition, patients with permanent coeliac disease initially had a significantly lower weight to height index, and their clinical relapse characteristics were more pronounced during rechallenge with gluten; they failed to thrive and suffered with diarrhoea and abdominal pains far more than those with abortive coeliac disease (Table IV). There was no significant difference between the two groups at the initial examination with regard to muscular hypotonia, the occurrence of anaemia, osteoporosis, as well as antigluten antibody titres during rechallenge with gluten. (Figs 1, 2, Table I). The dis cell count between the abortive and permanen groups prompted us to retrospectively analyse their clinical disparities. Although the duration of rechallenge to gluten was identical in both groups $(2.43(1.48)$ years for the permanent group versus $2.44(0.98)$ years for the abortive group) the severity of the reaction of the mucosa 


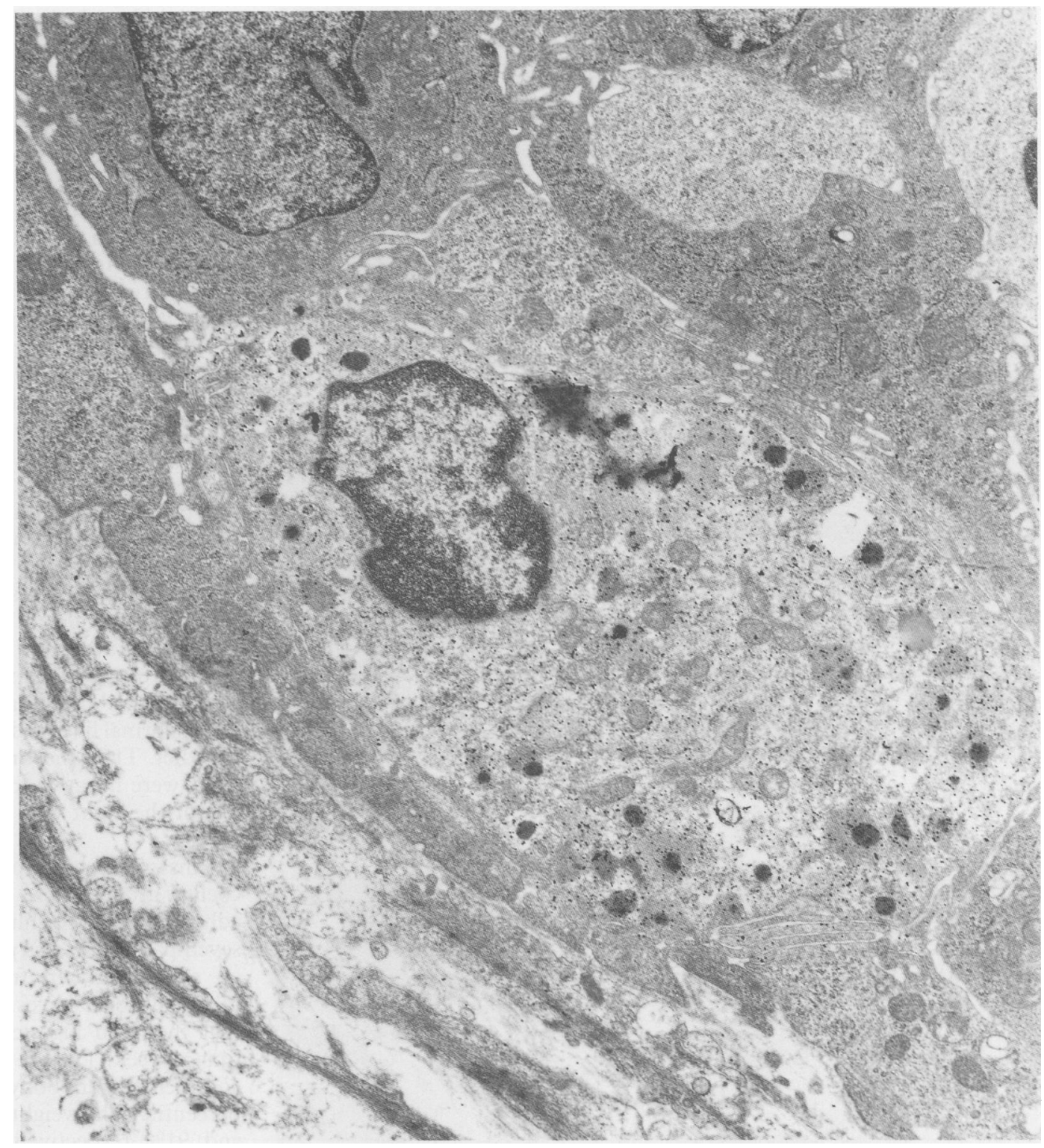

Figure 2: Electron microscope photomicrograph of a natural killer cell present within the epithelium. It has been characterised with a monoclonal antibody (anti-leu 11) and visualised with a gold enhancement procedure.

\section{Discussion}

Using the number of large granular lymphocytes and natural killer cells within the epithelium of the mucosa of the small intestine as a criterion has enabled us to identify two distinctly different groups of patients with coeliac disease that hitherto were considered to be a single entity. No inverse correlation was found to exist between the severity of the initial mucosal lesions and the number of large granular lymphocytes and natural killer cells within the epithelium of the gut. There was a more pronounced response of the intestinal mucosa to gluten in patients with permanent coeliac disease although the duration of the challenge was the same for both groups, and it was not related to the duration of time of the gluten free diet before challenge (Table III). Therefore, the severity of the mucosal pathology seems to be correlated with the occurrence of intraepithelial large granular lymphocytes and natural killer cells rather than to the duration of the challenge, and as well as the time of the gluten free diet. This contradicts the findings of
Shmerling and Franckx who considered that the duration of gluten challenge was an important factor in the pathological reaction of the mucosa. ${ }^{10}$ Although there are many intraepithelial lymphocytes in the gut, the large granular lymphocytes cells are but one type characterised by the presence of large granules within the cytoplasm. The cells are thought to be derived from the null cell line which do not consistently carry markers of either T or B cells. It is currently believed that this population of cells contains the majority of natural killer and antibody dependent cellular cytotoxic effectors. Only one third of these cells were positive for Leu-11 marker.

The results of our longterm study of patients with coeliac disease has confirmed what gastroenterologists have repeatedly advised over the years - that is, that patients with permanent coeliac diease must be maintained on a life long strict gluten free diet. Unfortunately, adherence to such a diet is not popular with teenage patients. It appears from our study that the 
TABLE II Characteristics of two groups of coeliac patients after gluten challenge

\begin{tabular}{lcc}
\hline & $\begin{array}{c}\text { Permanent type } \\
\text { of coeliac disease }\end{array}$ & $\begin{array}{l}\text { Abortive type } \\
\text { of coeliac disease }\end{array}$ \\
\hline $\begin{array}{l}\text { Patients (n) } \\
\begin{array}{l}\text { Mean age of patients when } \\
\text { the disease was diagnosed }\end{array}\end{array}$ & $5 \cdot 16(5 \cdot 17)$ & 8 \\
$\begin{array}{l}\text { Duration of gluten free } \\
\text { diet (years) }\end{array}$ & $4 \cdot 0(1 \cdot 85)$ & $2 \cdot 38(5 \cdot 5)$ \\
$\begin{array}{l}\text { Age when gluten challenge } \\
\text { was initiated (years) }\end{array}$ & $10 \cdot 11(5 \cdot 15)$ & $4 \cdot 83(4 \cdot 42)$ \\
$\begin{array}{l}\text { Duration of the challenge } \\
\text { (years) }\end{array}$ & $2 \cdot 43(1 \cdot 48)$ & $2 \cdot 44(0 \cdot 98)$ \\
$\begin{array}{l}\text { Duration of the disease } \\
\text { purat }\end{array}$ & $15 \cdot 9(4 \cdot 25)$ & $14 \cdot 2(3 \cdot 1)$ \\
\hline
\end{tabular}

TABLE III Average length (microns) of villi (SD) at the time of diagnosis (i), after a gluten free diet (ii), and after a gluten rechallenge (iii) in patients with abortive and permanent coeliac disease

\begin{tabular}{llll}
\hline Patients & $\begin{array}{l}\text { Time } \\
\text { period (i) }\end{array}$ & $\begin{array}{l}\text { Time } \\
\text { period (ii) } \dagger\end{array}$ & $\begin{array}{l}\text { Time } \\
\text { period (iii) }\end{array}$ \\
\hline $\begin{array}{c}\text { Abortive coeliac } \\
\text { disease }(\mathrm{n}=8)\end{array}$ & $11 \cdot 5(30 \cdot 6)$ & $355(66)$ & $\mid$ \\
$\begin{array}{c}\text { Permanent coeliac } \\
\text { disease }(\mathrm{n}=7)\end{array}$ & $1.43(3 \cdot 79)$ & $331(89)$ & $18.9(49)$ \\
\hline
\end{tabular}

${ }^{\star}$ ns: not significant, or $\mathrm{p}<0.01$ (Wilcoxon-Mann-Whitney-UTest); the normal height range of villi is between $325-500 \mu .^{12}$

patient's attitude towards such a diet is almost always determined by the type and severity of the disease. Those with permanent coeliac disease have perceived that they had to adhere to a strict diet. Non-adherence resulted in a severe weight loss, recurrent diarrhoea and anaemia. Our study also has revealed that all abortive coeliac patients who deliberately decided not to follow our advice to maintain a strict gluten free diet have remained, nevertheless, clinically asymptomatic (normal weight:height index, normal bowel movements, no anaemia, and negative antigluten antibody titres) during the entire follow up period of 15 years. The presence or absence of antigluten antibodies, particularly $\operatorname{IgA}$, in the serum of patients is an additional marker which indicates whether or not there has been dietary compliance. The absence of the antigluten antibodies is also further evidence of the presence of a normal gut mucosa which therefore negates the necessity of an additional biopsy of patients with abortive coeliac disease. It must be pointed out that what we consider as abortive coeliac disease is not the transient form of gluten intolerance that Visakorpi and Immonen ${ }^{11}$ and Walker-Smith ${ }^{6}$ have described. According to Walker-Smith, patients with the transient form of gluten intolerance retain a normal intestinal mucosa during a challenge with gluten. ${ }^{6}$ None of our patients, all of whom were older than two years of age, had a normal intestinal mucosa after a challenge with gluten; however, the mucosal changes in patients with the abortive form of the disease were less severe compared with the pathological changes seen in those with the permanent form of the disease. The abortive form is, however, similar to that reported by Schmitz et al, ${ }^{7}$ where four patients who also fulfilled all of the ESPGAN Criteria of coeliac disease; and in spite of a normal diet with
TABLE IV Characteristics of the two types of coeliac disease

\begin{tabular}{llll}
\hline & $\begin{array}{l}\text { Permanent } \\
\text { coeliac } \\
\text { disease }\end{array}$ & $\begin{array}{l}\text { Abortive } \\
\text { coeliac } \\
\text { disease }\end{array}$ & Probability \\
\hline $\begin{array}{c}\text { Weight to height } \\
\text { index }(</=85 \%)\end{array}$ & $100 \%(7 / 7)$ & $37 \cdot 5 \%(3 / 8)$ & $\mathrm{p}<0.05$ \\
$\begin{array}{c}\text { Flat mucosa after } \\
\text { gluten challenge }\end{array}$ & $86 \%(6 / 7)$ & $12 \cdot 5 \%(1 / 8)$ & $\mathrm{p}<0 \cdot 01$ \\
$\begin{array}{c}\text { Clinical relapse to } \\
\text { challenge }\end{array}$ & $86 \%(6 / 7)$ & $12 \cdot 5 \%(1 / 8)$ & $\mathrm{p}<0.01$ \\
$\begin{array}{c}\text { Patients with a normal } \\
\text { number of natural killer } \\
\text { and large granular } \\
\text { lymphocytes cells }(\%)\end{array}$ & $0 \cdot 0 \%(0 / 7)$ & $100 \%(8 / 8)$ & $\mathrm{p}<0 \cdot 01$ \\
$\begin{array}{c}\text { Patients on gluten free } \\
\text { diet }(\%)\end{array}$ & $100 \%(7 / 7)$ & $12 \cdot 5(1 / 8)$ & $\mathrm{p}<0.01$ \\
\hline
\end{tabular}

gluten challenges, have remained asymptomatic with subsequent normalisation of the mucosa. One of our patients in the abortive coeliac disease group, although having partial villus atrophy after gluten challenge, was maintained on a normal diet. Two years later, while she was asymptomatic, an additional biopsy was obtained. In spite of her diet, the intestinal biopsy was completely normal. This patient seemingly is similar to the four patients described by Schmitz, et $a l,{ }^{7}$ who provided clinical and histological data pertaining to the disease; we have been able to provide additional pathophysiological insight in the aetiology of this disease.

According to our results, the revised ESPGAN Criteria ${ }^{9}$ are insufficient to distinguish between permanent and abortive coeliac disease. The occurrence of gut epithelial large granular lymphocytes and natural killer cells offers an unique diagnostic approach for distinguishing the two different coeliac diseases which hitherto have been considered a single entity.

The question that remains to be answered is why patients with permanent coeliac disease develop a flare up during gluten provocation while those in the abortive group are more resistant to the toxic effect of gluten? In our opinion, the innocent bystander injury - that is, the adenovirus capable of triggering an immunological response in the small bowel leading to crypt hyperplastic villus atrophy ${ }^{13}$ together with a genetic predisposition (an impaired distribution of natural killer cells) are only two of the several possible explanations for the disparity between the two groups. It remains to be elucidated if only the number of natural killer and large granular lymphocytes cells, or their antiviral activity correlates with the difference in the severity of both diseases.

1 McNeish AS, Harms HK, Rey J, Shmerling DH, Visakorpi JK, Walker-Smith JA. Re-evaluation of diagnostic criteria for coeliac disease. Arch Dis Child 1979; 54: 783-6.

2 Walker-Smith JA. Management of coeliac disease in children: a personal view. In: Hadziselimovic F, Herzog B, BürginWolff A, eds. Inflammatory bowel disease and coeliac disease in Wolff A, eds. Inflammatory bowel disease and coeliac disease

3 Bürgin-Wolff A, Gaze H, Hadziselimovic F, Lentze M, Nusslé $D$. The diagnostic significance of gliadin and endoNusslé $D$. The diagnostic significance of gliadin and endomysium antibodies in childhood coeliac disease. In: Hadziselimovic F, Herzog B, Bürgin-Wolff A, eds. Inflammatory bowel disease and coeliac disease in children. Dordrecht: Kluwer Academic, 1990: 177-87.

4 Holmes GKT, Prior P, Lane MR, Pope D, Allan RN. Malignancy in coeliac disease - effect of a gluten-free diet. Gut 1989 ; 30: $333-8$

5 Kelly DA, Phillips AD, Elliott EJ, Dias JA, Walker-Smith JA The rise and fall of coeliac disease: 1960-1985. Arch Dis Child 1988; 69: 1157-60. 
6 Walker-Smith J. Transient gluten intolerance. Arch Dis Child 1970; 45: 523-6.

7 Schmitz J, Arnaud-Battandier F, Jos J, Rey J. Long term follow-up of childhood coeliac disease. Pediatr Res 1984; 18: 1052-5

8 Maxwell MH. Two rapid and simple methods used for the removal of resins form $1.0 \mu \mathrm{m}$ thick epoxy sections. 7 Microsc 1978; 112: 253-5.

9 Walker-Smith JA, Guandalini S, Schmitz J, Shmerling DH, Visakorpi JK Revised criteria for diagnosis of coeliac disease. Arch Dis Child 1990; 65: 909-11.

10 Shmerling DH, Franckx J. Childhood coeliac disease: a long- term analysis of relapses in 91 patients. $\mathcal{F}$ Pediatr Gastroenterol Nutr 1986; 5: 565-9.

11 Visakorpi JK, Immonen P. Intolerance to cow milk and wheat gluten in the primary malabsorption syndrome in infancy. Acta Paediatr Scandi 1967; 6: 49-56.

12 Kumar PJ, Walker-Smith J, Milla P, Harris G, Covler J, Halliday R. The teenage coeliac: follow up study of 102 patients. Arch Dis Child 1988; 63: 916-20.

13 Kagnoff MF, Paterson YJ, Kumar PJ, Kasarda DD, Carbone FR, Unsworth DJ, et al. Evidence for the role of a human intestinal adenovirus in the pathogenesis of coeliac disease. Gut 1987; 28: 995-1001 